\title{
Chronic ethanol consumption selectively stimulates rectal cell proliferation in the rat
}

\author{
U A SIMANOWSKI, H K SEITZ, B BAIER, B KOMMERELL, H SCHMIDT-GAYK, AND \\ N A WRIGHT
}

From the Department of Medicine and Surgery, University of Heidelberg, Heidelberg, FRG, and Department of Histopathology, Royal Postgraduate Medical School, Hammersmith Hospital, London

SUMmaRY Cell proliferation was examined in the gastrointestinal tract of 30 pair fed rats having received an isocaloric liquid diet containing $36 \%$ of total calories either as ethanol or carbohydrates for four weeks. Utilising the metaphase arrest technique with vincristine, cell proliferation was measured as crypt cell production rate. This was selectively increased in the rectal mucosa of ethanol fed rats $(19 \cdot 1 \pm 2 \cdot 0$ vs $9 \cdot 1 \pm 1 \cdot 8 \mathrm{cells} / \mathrm{crypt} / \mathrm{h} ; \mathrm{p}<0 \cdot 005)$. There was a concomitant increase in proliferative compartment size $(48 \cdot 1 \pm 5.6 \%$ vs $30 \cdot 1 \pm 8 \cdot 5 \%$ of crypt population size; $\mathrm{p}<0.001)$. Serum gastrin concentrations were also found to be significantly increased after ethanol feeding $(172 \pm 51$ vs $106 \pm 27 \mathrm{pmol} / 1 ; \mathrm{p}<0 \cdot 01)$. The ethanol dependent proliferative changes in the rectal mucosa are predictive of higher susceptibility of this site to carcinogenesis, supporting experimental and epidemiological data. Increased gastrin concentrations may partly explain the observed rectal hyperproliferation. Other possible causes cannot, however, be excluded.

Colorectal cancer is one of the most frequent malignancies in man, ${ }^{1}$ with the highest incidences occurring in industrialised countries. ${ }^{1}$ Immigrant studies $^{2}$ produced strong evidence for the role of environmental factors in the aetiology of colorectal cancer. Low dietary fibre content,${ }^{4}$ high fat intake ${ }^{5}$ and alcohol consumption (especially beer) ${ }^{6-8}$ have been shown to be associated with an increased risk of developing colorectal cancer. The implication of alcohol consumption in the aetiology of this malignancy was confirmed in animal studies ${ }^{9}{ }^{10}$ utilising the rat 1,2-dimethylhydrazine (DMH) colonic cancer model. Changes in epithelial cell kinetics play an important role in promotion of colorectal cancer. ${ }^{11} 12$ There are no data yet available, however, on cell kinetic changes in ethanol dependent colorectal tumor promotion. The purpose of this study was to examine kinetic behaviour of gastrointestinal epithelia after chronic ethanol ingestion, which had been proven to be cocarcinogenic in the rectum. ${ }^{9}$

\section{Methods}

ANIMALS AND DIETS

Thirty male Sprague-Dawley littermates of $220 \mathrm{~g}$

Address for correspondence: U A Simanowski, MD, Alcohol Research Laboratory, Department of Medicine, University of Heidelberg, Bergheimer Str. 58, 6900 Heidelberg, FRG.

Received for publication 5 July 1985 . body weight (Ivanovas, Kisslegg, FRG) were randomly paired and individually housed in wide metal wire cages. These animals were pair fed nutritionally adequate liquid diets. Thirty six percent of total calories were given either as ethanol or isocaloric carbohydrates as described by Lieber and DeCarli ${ }^{13}$ and modified by Seitz et al. ${ }^{9}$ Protein $(18 \%$ of calories) and lipid (35\% of calories) contents were thus the same, but the diets had different amounts of carbohydrates $(11 \%$ in the alcohol fed rats and $46 \%$ in the control rats). The ethanol concentration of the alcohol diet was $6 \cdot 6 \%(\mathrm{vol} / \mathrm{vol})$. Liquid diets were renewed every day at $2.00 \mathrm{pm}$, so that the animals consumed ethanol continuously.

CELL PROLIFERATION STUDIES

After four weeks of pairfeeding, animals were injected ip with $1 \mathrm{mg}$ vincristine/ $\mathrm{kg}$ body weight at 9.00 am and one pair of rats was killed by cervical dislocation at each of the following time points (minutes after vincristine: $30,35,40,45,60$, then every 10 minutes until 160 minutes. Tissue samples were taken from the lower oesophagus, antral region of the stomach, duodenum $(3 \mathrm{~cm}$ distal of the pylorus), ileum (10 $\mathrm{cm}$ proximal of the ileocaecal valve), proximal colon $(3 \mathrm{~cm}$ distal of the ileocaecal valve) and rectum (3 $\mathrm{cm}$ proximal to the external anal sphincter). Osophageal tissue and half of the rectal tissue samples were fixed and kept in $10 \%$ 
neutral buffered formalin. All other tissue was fixed in Carnoys fixative (6 parts ethanol, 1 part acetic acid, 2 parts chloroform) for approximately four hours, and stored in $70 \%$ ethanol thereafter. ${ }^{14}$ Transverse sections, $3 \mu \mathrm{m}$ in thickness, were cut from paraplast embedded formalin fixed tissue and stained with haematoxylin and eosin. The tissue was sectioned as follows: oesophagus: transverse sections; rectum: transverse and longitudinal sections to reveal longitudinally and cross sectioned crypts. Approximately 2000 basal cells per oeosphageal sample were examined for mitotic figures. The mitotic index (mitoses per 1000 cells) was plotted against time after vincristine. From all other locations of the digestive tract, small samples of about $2 \times 2 \mathrm{~mm}$ size were dehydrated, stained by the Feulgen reaction and crypt squashes prepared by microdissection. ${ }^{14}$

Metaphase figures were counted in 10 to 100 crypts per animal and site, and the mean plotted against time for each site. All counting was done by the same person, who was not aware of the identity of the samples. Metaphase arrest lines were fitted by least squares linear regressions. The slopes of the lines give the crypt cell production rates (CCPR) in cells per crypt per hour in stomach and intestine and the birth rate expressed as cells per 1000 cells per hour for the oesophagus. ${ }^{15}$ For estimation of the size of the proliferative compartment (PC) a graphical method was used, determining the $50 \%$ peak value of the mitotic index distribution curve. ${ }^{16}$ Crypt sizes were analysed for treated and control animals by counting cells per crypt column of 200 longitudinally

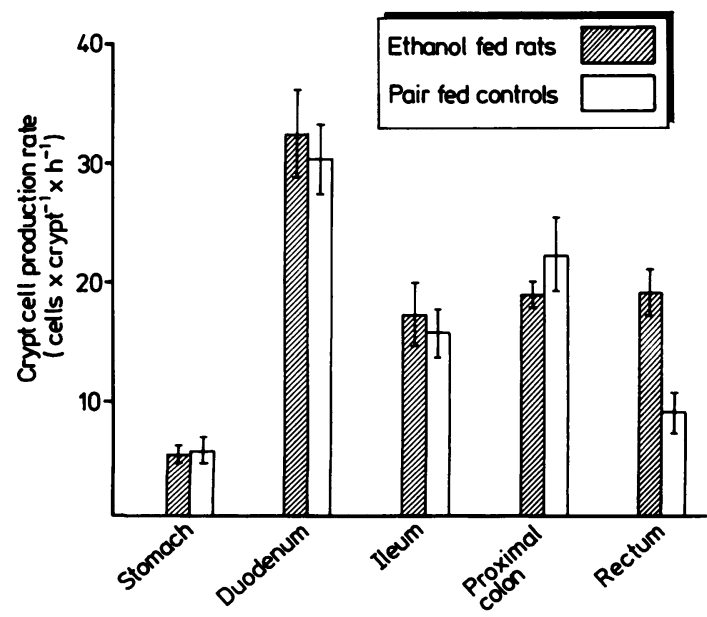

Fig. 1 Effect of chronic ethanol ingestion on crypt cell production rate in various sites of the gastrointestinal tract. Only in the rectum a significant difference $(p<0.005)$ was noted. sectioned crypts and cells per circumference of 150 cross sectioned crypts. At the time of death, blood was sampled for gastrin radioimmunoassay. Samples were randomised and coded before being processed. In addition, serum ethanol concentrations were measured by gas chromatography.

\section{STATISTICAL ANALYSIS}

Results are given as means \pm SD. The slopes of regression lines of control and treated animals were compared at each site, using the unpaired two sided Student's $t$ test. Gastrin values and PC sizes were compared using the Student's $t$ test for paired data.

\section{Results}

All tissues of ethanol fed and control animals appeared normal, as judged by light microscopy.

In the squamous epithelium of the oesophagus ethanol feeding did not influence the birth rate $(27.5 \pm 5.3$ vs $23.3 \pm 1.5$ cells $/ 1000$ cells $/ \mathrm{h} ; \mathrm{p}>0.05)$. In addition, no alcohol mediated effect was found in the stomach, duodenum, ileum and proximal colon (Fig. 1). In the rectum, however, there was a significant $2 \cdot 1$ fold increase of CCPR in ethanol treated animals when compared with controls (Fig. 1). Crypt sizes were not altered by alcohol ingestion: The column count was $39 \cdot 3 \pm 6 \cdot 6$ vs $36 \cdot 9 \pm 5 \cdot 4$ cells/ crypt column $(\mathrm{p}>0.05)$ and the circumferential count was $14.8 \pm 2.3$ vs $14.7 \pm 2.5$ cells/circumference $(\mathrm{p}>0.05)$.

The proliferative compartment size was significantly extended towards the rectal lumen after chronic ethanol feeding (Fig. 2). The proliferative compartment comprised $48.1 \pm 5.6 \%$ in alcohol treated rats and $30.1 \pm 8.5 \%(\mathrm{p}<0.001)$ in controls, related to the actual crypt size.

After four weeks of pairfeeding liquid diets, the serum gastrin concentrations were significantly increased in alcohol fed animals (172 \pm 51 vs $106 \pm 27$ $\mathrm{pmol} / \mathrm{l} ; \mathrm{p}<0.01)$. Mean serum ethanol concentration at the time of death was $197 \pm 59 \mathrm{mg} / 100 \mathrm{ml}$.

\section{Discussion}

Alcohol consumption has a clear hyperproliferative effect in the rat rectum. In other parts of the gastrointestinal tract, however, no such effect was demonstrable. Features of this hyperproliferative state were an increased cell production per crypt expressed as raised CCPR and an upward extension of the proliferative compartment comprising the lower half of crypts in ethanol fed rats, whereas in control animals the proliferative compartment did not exceed the lower third of the crypts. This hyperproliferative state did not, however, result in 


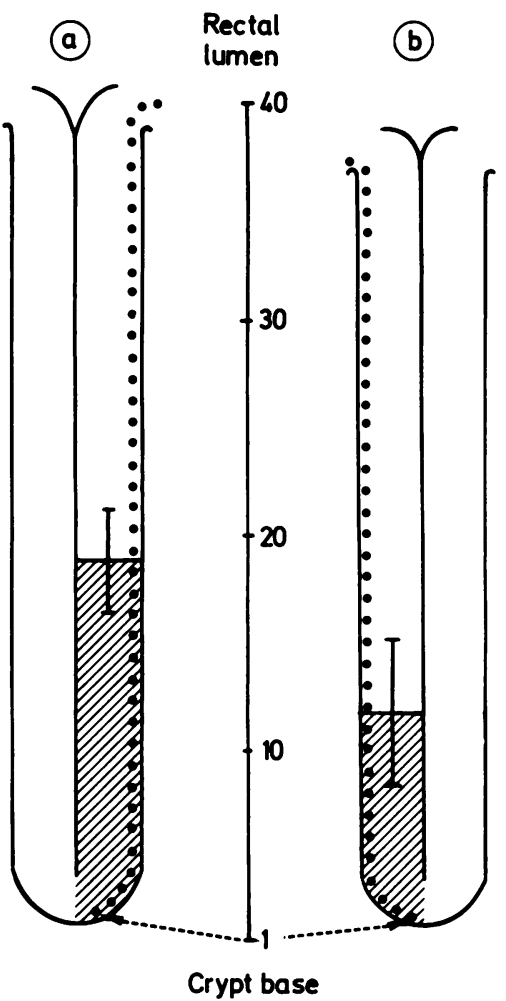

Fig. 2 Effect of chronic ethanol ingestion on proliferative compartment size in rectal crypts. (a) Crypts in ethanol fed rats (b) Crypts in pair fed controls. The hatched area shows the proliferative compartment. The difference was statistically significant $(p<0.001)$.

hyperplastic mucosa, as the crypt size (cells per crypt) was unchanged. When calculating the life span of cells in the functional compartment, - that is, (crypt cell number - PC cell number)/CCPR, alcohol feeding led to a life span reduction of $61 \%$ (16 hours vs 41 hours).

Surprisingly chronic ethanol feeding resulted in cell proliferative changes only in the rectum and not in other parts of the gastrointestinal tract. The available data on cell regeneration in the upper gastrointestinal tract are controversial. Tritiated thymidine incorporation studies indicate increased cell proliferation, ${ }^{17}{ }^{18}$ whereas mitotic index determination suggests depressed cell renewal in the small intestine after chronic ethanol consumption. ${ }^{19}$ Compared with the metaphase arrest technique, however, these methods, especially when using mucosal scrapings seem to be rather insensitive and questionable. ${ }^{20}$ Proliferative indices such as the mitotic index or labelling index are 'state measure- ments' - that is, they reliably reflect changes in proliferative activity only, if cell cycle phases are constant. Increased proliferation for example, may not result in a higher mitotic index, when the duration of mitosis is decreased simultaneously. Changes in gastrointestinal cell proliferation are, however, often due to changes in cell cycle phases, ${ }^{21}{ }^{22}$ hence a dynamic measurement, like the metaphase arrest technique, is preferable.

As hyperproliferation plays an important role in tumour promotion, it is of relevance that chronic alcohol ingestion also caused an increased rectal tumour incidence. ${ }^{9}$ It has to be emphasised that in the carcinogenic experiments by Seitz et al, liquid diets and rat strain were identical to those used in the present study. Increased cell proliferation is involved in carcinogenesis in two distinct phases: namely during promotion and as preexisting epithelial status, that is before initiation. In DMH treated animals mucosal hyperplasia and enlargement of proliferative compartment is found, ${ }^{11}$ characterising the phase of promotion. Non-hyperplastic hyperproliferative changes similar to those observed with alcohol in the present study that is, enlarged proliferative compartment without crypt size increase, may also occur in the promotion phase after DMH treatment in rats. ${ }^{23}$

In the context of this study, however, it seems to be more important that the preexisting proliferative status has implications for the susceptibility of the target tissue to carcinogens. Increased tumour incidences were observed in a variety of hyperproliferative conditions in the colon: in the rat caecum after ligature insertion, ${ }^{11}$ after cholic acid feeding, ${ }^{24}$ after small bowel resection, ${ }^{25}$ and in ulcerative colitis in man. ${ }^{26} 27$ Hyperproliferation and expansion towards the colonic lumen of the proliferative compartment as observed here with ethanol appear to be predictive of increased susceptibility to chemical carcinogenesis. ${ }^{28} 29$ Thus, Lipkin utilises proliferative compartment changes for risk assessment with respect to colorectal cancer. ${ }^{30} 31$

Taking these data into account, our observations are highly suggestive of a link between rectal hyperproliferation and rectal tumour promotion. Thus, enhanced rectal cell proliferation may be at least one mechanism explaining the cocarcinogenic effect of alcohol on this tissue. ${ }^{9}$

The means by which alcohol brings about rectal hyperproliferation, however, remain unclear. Mucosal alcohol dehydrogenase (ADH) activities are selectively increased in rectal mucosa after prolonged ethanol ingestion, ${ }^{9}$ matching the distribution of hyperproliferation. Indeed, an association has been recognised between rectal ADH activity and the number of luminal epithelial cells. ${ }^{32}$ An 
increased rectal ADH activity may lead to an accumulation of acetaldehyde, a toxic ethanol metabolite, in rectal epithelial cells. ${ }^{33}$ Morphological alterations observed in rectal biopsies ${ }^{34}$ from alcoholics as well as the reduced life span of functional epithelial cells shown in this study may be indicative of such toxic events. Thus, hyperproliferation would be of secondary, compensatory nature.

Subsequently, the high serum gastrin concentrations in alcohol treated animals may be associated with rectal hyperproliferation. Although effects of gastrin on intestinal cell proliferation remain controversial, ${ }^{35}{ }^{36}$ there is some evidence that gastrin causes hyperproliferative hyperplasia mainly in the colon. ${ }^{35}{ }^{37}$ There are currently no data available as to whether the rectal mucosa is preferred by the stimulatory action of gastrin. Furthermore, we did not observe hyperplasia in the ethanol fed hypergastrinemic animals.

The mechanism and the reason for the rectal preference of the observed hyperproliferation following chronic ethanol ingestion remain unclear. Further investigations are needed to determine whether these findings are also evident in humans, especially with respect to the increased incidence of rectal cancer found in the alcoholic. ${ }^{6-8}$

The authors wish to thank Mrs S Veith, B Sulger and I Ferschke for their expert technical assistance. This study was supported by a grant of the Deutsche Forschungsgemeinschaft Se 333/6-1.

\section{References}

1 Wynder EL. The epidemiology of large bowel cancer. Cancer Res 1975; 35: 3388-94.

2 Stemmermann GN. Patterns of disease among Japanese living in Hawaii. Arch Environ Health 1970; 20: 266-73.

3 Wynder EL, Kajitani T, Ishikawa S, Dodo H, Takano A. Environmental factors of cancer of the colon and rectum - II. Japanese epidemiological data. Cancer 1969; 23: 1210-20.

4 Correa P. Epidemiological correlations between diet and cancer frequency. Cancer Res 1981; 41: 3685-90.

5 Reddy BS. Dietary fat and its relationship to large bowel cancer. Cancer Res 1981; 41: 3700-5.

6 Pollack ES, Nomura AMY, Heilbrun LK, Stemmermann GN, Green SB. Prospective study of alcohol consumption and cancer. $N$ Engl J Med 1984; 310: 617-21.

7 Dean G, McLennan P, McLoughlin P. The cause of death in blue collar workers at a Dublin brewery 1954-1973. Br J Cancer 1979; 40: 581-9.

8 Enstrom JE. Colorectal cancer in beer drinking. $\mathrm{Br} J$ Cancer 1977; 35: 674-83.

9 Seitz HK, Czygan P, Waldherr R, et al. Enhancement of 1,2-dimethylhydrazine induced rectal carcinogenesis following chronic ethanol consumption in the rat. Gastroenterology 1984; 86: 886-91.

10 Hamilton SR, Hyland J, McAvinchey D, Boitnott JK. Effects of dietary beer or ethanol on experimental colonic carcinogenesis. [Abstract]. Gastroenterology 1983; 84: 1180 .

11 Wright NA. The histogenesis of gastrointestinal cancer. In: Hodgson HJF, Bloom SR, eds. Gastrointestinal and hepatobiliary cancer. London: Chapman and Hall, 1983: 79-117.

12 Deschner EE, Raicht RF. Influence of bile on kinetic behavior of colonic epithelial cells of the rat. Digestion 1979; 19: 322-7.

13 Lieber CS, DeCarli LM. Quantitative relationship between the amount of dietary fat and the severity of alcoholic fatty liver. Am J Clin Nutr 1970; 23: 474-8.

14 Goodlad RA, Wright NA. Quantitative studies on epithelial replacement in the gut. In: Titchen DA, ed. Techniques in the life sciences. Digestive physiology. County Clare: Elsevier Biomedical, 1982; 1-23.

15 Wright NA, Appleton DR. The metaphase arrest technique. Cell Tissue Kinet 1980; 13: 643-63.

16 Wright NA, Watson A, Morley A, Appleton DR, Marks J. Cell kinetics in flat (avillous) mucosa of the human small intestine. Gut 1973; 14: 701-10.

17 Baraona E, Pirola RC, Lieber CS. Small intestinal damage and changes in cell population produced by ethanol ingestion in the rat. Gastroenterology 1974; 66: 226-34.

18 Seitz HK, Czygan P, Kommerell B. Stimulation of thymidine incorporation in isolated rat intestinal mucosal cells by feeding an ethanol containing liquid diet. Digestion 1982; 23: 65-7.

19 Zucoloto S, Rossi MA. Effect of chronic ethanol consumption on mucosal morphology and mitotic index in the rat small intestine. Digestion 1979; 19: 277-83.

20 Al-Mukhtar MYT, Polak JM, Bloom SR, Wright NA. The search for appropriate measurements of proliferative and morphological status in studies on intestinal adaption. In: Robinson JWL, Dowling RH, Riecken ED, eds. Mechanisms of intestinal adaption. Lancaster: MTP Press, 1982: 3-25.

21 Al-Dewachi HS, Wright NA, Appleton DR, Watson AJ. Studies on the mechanism of diurnal variation of proliferative indices in the small bowel mucosa of the rat. Cell Tissue Kinet 1976; 9: 459-67.

22 Al-Dewachi HS, Wright NA, Appleton DR, Watson AJ. The effect of starvation and refeeding on cell population kinetics in the rat small bowel mucosa. $J$ Anat 1975; 119: 105-21.

23 Pozharisski KM. Morphology and morphogenesis of experimental epithelial tumors of the intestine. JNCI 1975; 54: 1115-35.

24 Cohen BP, Raicht RF, Deschner EE, Takahashi M, Sarwal AN, Fazzini E. Effect of cholic acid feeding on $\mathrm{N}$-methyl-N-nitrosurea-induced colon tumors and cell kinetics in rats. JNCI 1980; 64: 573-8.

25 Williamson RCN, Malt RA. Promotion of intestinal carcinogenesis by adaptive mucosal hyperplasia. In: Appleton DR, Sunter JP, Watson AJ, eds. Cell proliferation in the gastrointestinal tract. London: Pitman Medical, 1980: 303-15. 
26 Bleiberg $\mathrm{H}$, Mainguet $\mathrm{P}$, Galand $\mathrm{P}$, Chretien $\mathrm{J}$, Dupont-Mairesse $\mathrm{N}$. Cell renewal in the human rectum. In vitro autoradiographic study on ulcerative colitis. Gastroenterology 1970; 58: 851-5.

27 Earnshaw P, Busuttil A, Ferguson A. Relevance of colonic mucosal inflammation to aetiology. In: Duncan W, ed. Recent results in cancer research. Colorectal cancer. Berlin: Springer Verlag, 1982: 31-44.

28 Deschner EE, Long FC, Hakissian M, Herrmann SL. Differential susceptibility of AKR, C57B1/6J, and CF1 mice to 1,2-dimethylhydrazine-induced colonic tumor formation predicted by proliferative characteristics of colonic epithelial cells. JNCI 1983; 70: 279-82.

29 Deschner EE, Long FC, Hakissian M, Cupo SH. Differential susceptibility of inbred mouse strains forecast by acute colonic proliferative response to methylazoxymethanol. JNCI 1984; 72: 195-8.

30 Lipkin M. Early identification of population groups at high risk for gastrointestinal cancer. In: Malt RA, Williamson RCN, eds. Colonic carcinogenesis. Lancaster: MTP Press Limited, 1981: 31-46.

31 Lipkin M. Method for binary classification and risk assessment of individuals with familial polyposis based on ${ }^{3} \mathrm{H}-\mathrm{TdR}$ labelling of epithelial cells in colonic crypts. Cell Tissue Kinet 1984; 17: 209-22.
32 Pestalozzi DM, Bühler R, von Wartburg JP, Hess M. Immunohistochemical localisation of alcohol dehydrogenase in the human gastrointestinal tract. Gastroenterology 1983; 85: 1011-6.

33 Lindros KO. Acetaldehyde - its metabolism and role in the action of alcohol. In: Israel Y, Glaser FB, Kalant H, Pophan RE, Schmidt W, eds. Research advance in alcohol and drug problems. New York: Plenum Press Corp, 1978: 111-76.

34 Brozinsky S, Fami K, Grosberg JJ. Alcohol ingestion induced changes in the human rectal mucosa: light and electron microscopic studies. Dis Colon Rectum 1979; 21: $329-35$.

35 Johnson LR. Trophic effects of gastrin on the colon. In: Wolman SR, Mastromarino AJ, eds. Markers of colonic cell differentiation. New York: Raven Press, 1984: 327-36.

36 Goodlad RA, Al-Mukhtar MYT, Ghatei MA, Bloom SR, Wright NA. Cell proliferation, plasma enteroglucagon and plasma gastrin levels in starved and refed rats. Virchows Arch [Cell Pathol] 1983; 43: 55-62.

37 Fatemi SH, Cullan GE, Sharp JG. Evaluation of the effects of pentagastrin, gastrin and pancreatic glucagon on cell proliferation in the rat gastrointestinal tract. Cell Tissue Kinet 1984; 17: 119-33. 